\title{
OPEN Oceanic and super-deep continental diamonds share a transition zone origin and mantle plume transportation
}

\author{
Luc S. Doucet ${ }^{\bowtie}$, Zheng-Xiang Li ${ }^{\bowtie}$ \& Hamed Gamal El Dien
}

Rare oceanic diamonds are believed to have a mantle transition zone origin like super-deep continental diamonds. However, oceanic diamonds have a homogeneous and organic-like light carbon isotope signature $\left(\delta^{13} \mathrm{C}-28\right.$ to $-20 \%$ ) instead of the extremely variable organic to lithospheric mantle signature of super-deep continental diamonds $\left(\delta^{13} \mathrm{C}-25 \%\right.$ to $+3.5 \%$ ). Here, we show that with rare exceptions, oceanic diamonds and the isotopically lighter cores of super-deep continental diamonds share a common organic $\delta^{13} \mathrm{C}$ composition reflecting carbon brought down to the transition zone by subduction, whereas the rims of such super-deep continental diamonds have the same $\delta^{13} \mathrm{C}$ as peridotitic diamonds from the lithospheric mantle. Like lithospheric continental diamonds, almost all the known occurrences of oceanic diamonds are linked to plume-induced large igneous provinces or ocean islands, suggesting a common connection to mantle plumes. We argue that mantle plumes bring the transition zone diamonds to shallower levels, where only those emplaced at the base of the continental lithosphere might grow rims with lithospheric mantle carbon isotope signatures.

The vast majority of diamonds have grown in the old continental lithospheric mantle between 150 and $300 \mathrm{~km}$ depths ${ }^{1}$ and are found in mantle xenoliths in kimberlites, lamproite, lamprophyres and related placer deposits. The positions of these deposits relative to plume magmatism and the large low sheared wave velocity province $(\text { LLSVP })^{2}$ suggest that they are related to mantle plume events ${ }^{2-5}$. A small fraction (1\%) of the continental diamonds have mineral inclusions that suggest a deeper origin of between $\sim 300$ and $1000 \mathrm{~km} \mathrm{depths} s^{6}$, and are known as super-deep or sub-lithospheric continental diamonds ${ }^{7}$. Super-deep continental diamonds have extremely variable carbon isotopic compositions $\left(\delta^{13} \mathrm{C} \text { from }-25 \text { to }+3.5 \%\right)^{8-11}$, in contrast to a dominant mode of carbon isotope at around $-5 \%$ exhibited by lithospheric peridotitic and eclogitic diamonds ${ }^{12}$.

An even smaller fraction $(<<1 \%)$ of diamonds are found in the oceanic lithosphere sampled by mantle xenoliths or preserved in ophiolitic belts worldwide ${ }^{13-17}$ (Fig. 1). Such oceanic diamonds share morphological similarities with synthetic diamonds, e.g., they are euhedral to subhedral with cubo-octahedral shape and low nitrogen aggregation, which led some to question their natural origin ${ }^{18,19}$. However, oceanic diamonds display features, such as inclusions (e.g., coesite and feldspar), presence of moissanite ( $\mathrm{SiC})$, and a large continuous range of $\delta^{15} \mathrm{~N}$ isotopic composition $\left(-5.6 \%\right.$ to $+28.7 \%$ ), not found in synthetic diamonds ${ }^{20-22}$. In situ occurrence of such natural diamonds have also been demonstrated by thin-section in situ petrographic observations ${ }^{23,24}$. Some studies proposed that diamonds found in ophiolites could have resulted from serpentinisation processes ${ }^{22,25}$. However, the presence of ultra-high-pressure and highly reduced mineral phases in such diamonds suggests their formation at $>300 \mathrm{~km}$ depths ${ }^{26}$, which cannot be explained by serpentinization ${ }^{27}$. Moreover, although diamond nano-particles can form under thermodynamic instability and low pressure-temperature conditions ${ }^{28,29}$, this mechanism is incompatible with the nano- to micro-meter sizes of the oceanic diamonds ${ }^{30}$, and cannot reproduce fluid inclusions with complex compositions (in $\mathrm{Na}, \mathrm{Cl}, \mathrm{K}$ ) similar to kimberlitic and ultra-high pressure (UHP) metamorphic diamonds ${ }^{31,32}$.

On the other hand, these oceanic diamonds share similar characteristics to super-deep continental diamonds in that they, in general, are microdiamonds $\left(<1 \mathrm{~mm}\right.$ in size ${ }^{35}$, except for the exceptionally large CLIPPIR diamonds ${ }^{36}$ ) and are associated with a range of ultra-high-pressure and highly reduced mineral phases (e.g., coesite, kyanite, UHP nitride, $\mathrm{SiC}, \mathrm{Ni}-\mathrm{Mn}$ alloys, $\mathrm{Fe}-\mathrm{Si}$ and $\mathrm{Fe}-\mathrm{C})^{12,15,16}$. It is thus believed that oceanic diamonds and super-deep continental diamonds formed in the volatile-rich regions of the mantle, most likely in 


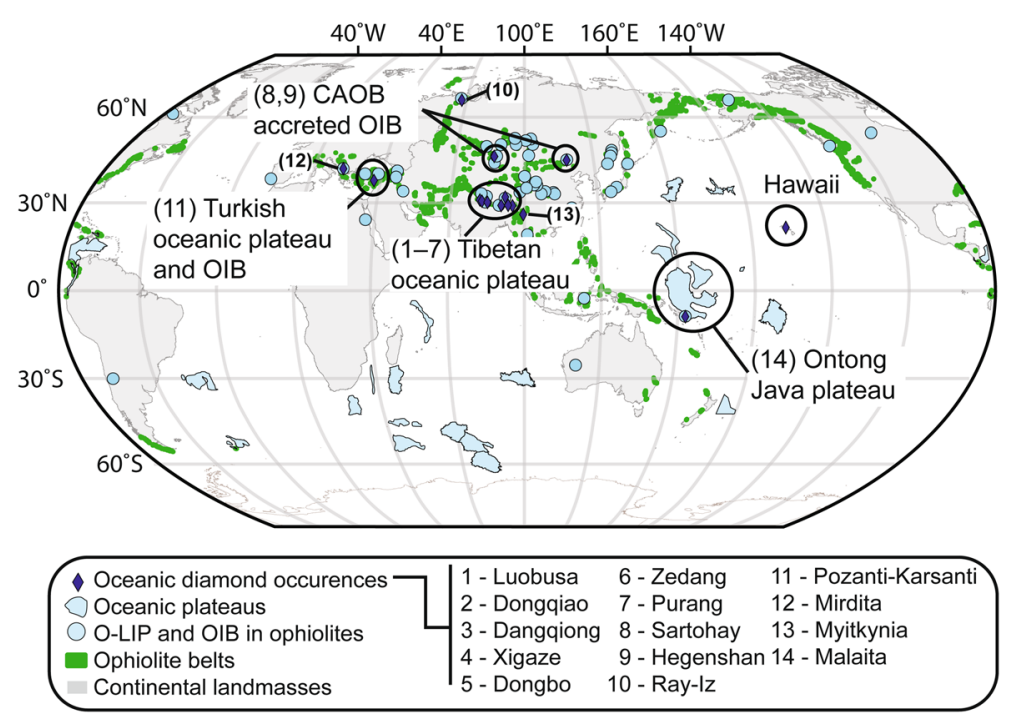

Figure 1. Map showing oceanic diamond and oceanic mantle plume occurrences. The data are from Lian and Yang ${ }^{16}$ and Doucet et al. ${ }^{33}$. The world map is made using GPlate 2.2 open-source software (licensed under the GNU General Public License version 2 https://www.gplates.org/) with open-source coastline data from Matthews et al. ${ }^{34}$ (licensed under Creative Common Attribution 4.0 International License https://www.earth byte.org/category/resources/).

the transition zone $(410-660 \mathrm{~km})^{12,16}$. It is widely accepted that such diamonds (and related ultra-high pressure and reduced mineral phases) formed from an oxidized, $\mathrm{CO}_{3}$-rich melt ${ }^{37-41}$ or reduced fluids produced when subducted slabs melted after entering the transition zone, where the pressure is $15-16 \mathrm{GPa}$, temperature $\sim 1600{ }^{\circ} \mathrm{C}$, and volatile contents $1-1.5 \mathrm{wt} \%^{36,42,43}$.

Despite their similarities, oceanic diamonds and super-deep continental diamonds do display significant differences. First, oceanic diamonds found in ophiolites occur as inclusions in podiform chromitites, which is different from the occurrence of superdeep continental diamonds. Second, oceanic diamonds show a homogeneous carbon isotopic composition $\left(\delta^{13} \mathrm{C} \text { from }-28 \text { to }-20 \%\right)^{30,32,44}$ (Fig. $2 \mathrm{c}$ ) whereas super-deep continental diamonds exhibit extreme isotopic variabilities $\left(\delta^{13} \mathrm{C} \text { from }-25 \text { to }+3.5 \% \text { o }\right)^{8-11}$ (Fig. $\left.2 \mathrm{~b}\right)$. Third, some superdeep diamonds from Juina have oxidized inclusions such as carbonate minerals (magnesite, eitelite, nyerereite and nahcolite ${ }^{45-47}$, which are not found in oceanic diamonds. Hence, the relationship between super-deep continental diamonds and oceanic diamonds remains elusive, and it is unclear how the oceanic diamonds get incorporated into the oceanic upper mantle before being brought to the surface either as part of mantle xenoliths or part of ophiolites.

Two main mechanisms have been proposed to explain the transportation of oceanic diamonds from the transition zone to the upper mantle: (1) subduction return flow ${ }^{52,53}$, or (2) mantle upwelling ${ }^{15}$. In the first model, gravity causes the subducting slab to roll back, which triggers return flows that brings the diamonds and ultrahigh-pressure minerals to the shallower levels within the subduction channel. In the second model, mantle upwellings, possibly induced by the pondering of plume heads on the transition zone, brings the diamonds and ultra-high-pressure minerals to the lithospheric mantle, fragments of which are later accreted onto the continental margin during subduction.

In this contribution, we aim to achieve a coherent mechanism for the origin of both the oceanic diamonds and the super-deep continental diamonds, including processes that brought them to the surface. We test the various models by investigating the oceanic diamond record together with a compilation of oceanic large igneous provinces (O-LIPs) and ocean island basalts (OIBs) database, or O-LIPdb ${ }^{33}$, which includes geological and geochemical evidence for plume-related materials in ophiolites ${ }^{54}$. We show that most oceanic diamonds found in ophiolite belts are not associated with classic ophiolitic sequences that represent the normal oceanic lithosphere formed at mid-ocean ridges; instead, they are associated with plume-modified O-LIP or OIB lithospheric fragments preserved in ophiolite belts.

\section{Results}

We observe a striking correlation between the occurrence of oceanic diamonds in either present-day oceanic rocks $^{13,14}$ or ancient ophiolites ${ }^{15,16}$, and the oceanic mantle plume record ${ }^{33}$ (Fig. 1; Table 1). The correlation is most obvious when only considering the modern oceanic diamonds, as both the Hawaiian and Malaita islands examples (Fig. 1) are known to be of plume origin. Diamond inclusions are found in garnet-bearing xenoliths from the Malaita islands, the exhumed portion of the southwest Ontong Java oceanic plateau. Both seismic data and mantle xenolith studies there point to a mantle lithosphere thicker than $130-140 \mathrm{~km}^{55-58}$. Such a thickened oceanic lithosphere, together with the highly depleted nature of the mantle lithosphere in these two regions, is consistent with their plume origin ${ }^{59}$.

From the ophiolite record (Table 1; Fig. 1), the Tibetan ophiolites from the Yarlung-Zhanbo belt, which are the remnants of the lithospheric mantle of Tethyan oceanic plateau(s) ${ }^{60,61}$ (Fig. 3), provide the most frequent 


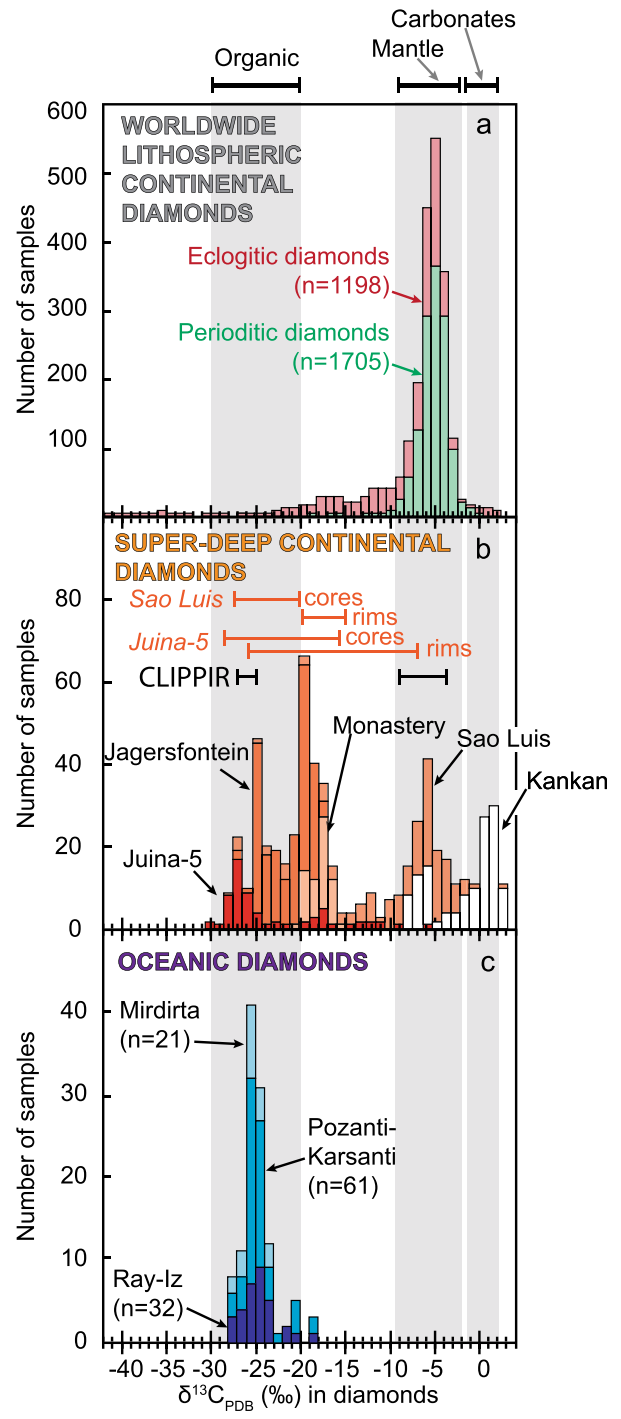

Figure 2. Carbon isotope composition of diamonds (expressed as $\delta^{13} \mathrm{C}$ relative to Pee Dee Belemnite). (a) Worldwide lithospheric continental diamonds ${ }^{12}$ showing eclogitic (pink) and peridotitic diamonds (green). (b) Super-deep continental diamonds ${ }^{8-11}$ from Juina-5, Jagersfontein, Monastery, Sao Luis and Kankan. Also shown are the carbon isotope ranges for the cores and rims of the Sao-Luis ${ }^{8}$ and Juina- $5^{10}$ diamonds, and data reported for seven fragments of CLIPPIR diamonds ${ }^{36}$. (c) Oceanic diamonds from Mirdirta ${ }^{32}$, Pozanti-Karsanti ${ }^{44}$ and Ray- $\mathrm{Iz}^{30}$. The carbon isotope range for the mantle is from Deines ${ }^{48}$, the ranges for carbonates and organic matter are from studies of sedimentary rocks of the entire geological record ${ }^{49-51}$.

occurrences of oceanic diamonds (Fig. 1). The Sartohay (part of the Darbut ophiolitic melange) and Hegenshan ophiolites are associated with accreted OIBs in the Central Asian Orogenic Belt (CAOB) in the West Jungaar suture zone ${ }^{62}$ and the Inner Mongolia-Daxinganling orogenic belt ${ }^{63}$, respectively, both exhibiting O-LIP characteristics $^{33}$. The Pozanti-Karsanti (also known as Aladag) ophiolite in Turkey is part of the eastern Tau-

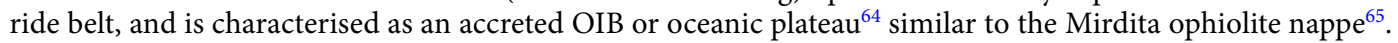
Although the original authors interpreted the Ray-Iz and Myitkynia ophiolites to be of suprasubduction origin without plume involvement, we found that the mafic and ultramafic rocks from these two ophiolites share similar geochemical features to the plume-modified oceanic lithosphere (Fig. 3 and Figures S3 and S4). Diamonds from these two ophiolites also share similar features as the O-LIP/OIB-related diamonds: the presence of ultra-high pressure minerals and highly-reduced phases, and very low $\delta^{13} \mathrm{C}$ (i.e. -30 to $-20 \%$ or the Ray-Iz diamonds) (Fig. 2) 27,66. We thus consider them to be plume-related diamond-bearing ophiolites as well.

In addition, the magmatic ages of diamond-bearing ophiolites (Table 1) also coincide with the peaks of oceanic mantle plume activities for the last 500 million years at 430, 395, 165, 125 and 95 million years ago (Fig. 4) ) $^{33}$. These peaks reflect an increase in mantle plume activity with time, interpreted to be the result of global mantle dynamics driven by the supercontinent cycle ${ }^{70,71}$. This observation further reinforces a plume connection for oceanic diamonds. A similar general correlation between continental plume record and diamondiferous kimberlites suggest the same connection for continental diamonds ${ }^{72,73}$. 


\begin{tabular}{|c|c|c|c|c|c|c|c|c|c|c|c|}
\hline & Lat. decimal & $\begin{array}{l}\text { Long. } \\
\text { decimal }\end{array}$ & $\begin{array}{l}\text { Magmatic } \\
\text { age m.y }\end{array}$ & $\begin{array}{l}\text { Emplacement } \\
\text { age m.y }\end{array}$ & Location & $\begin{array}{l}\text { Diamond } \\
\text { discovery }\end{array}$ & Plume type & $\begin{array}{l}\text { Tectonic } \\
\text { setting } \\
\text { reference }\end{array}$ & $\begin{array}{l}\text { Location } \\
\text { name }\end{array}$ & \begin{tabular}{|l|} 
Tectonic \\
settings of \\
ophilolite \\
fragments \\
\end{tabular} & Note \\
\hline \multicolumn{12}{|c|}{ Diamonds in xenoliths } \\
\hline $\begin{array}{l}\text { Salt-lake } \\
\text { crater }\end{array}$ & 21.47 & -158.00 & 0.44 & & $\begin{array}{l}\text { O’ahy, } \\
\text { Hawaii }\end{array}$ & \begin{tabular}{|l} 
Wirth and \\
Rocholl $^{14}$
\end{tabular} & OIB & $\begin{array}{l}\text { Wirth and } \\
\text { Rocholl }^{14}\end{array}$ & Hawaii & & \\
\hline Malaita & -9.05 & 161.19 & 34 & & $\begin{array}{l}\text { Malaita } \\
\text { Island }\end{array}$ & $\begin{array}{l}\text { Collerson } \\
\text { et al. }{ }^{13}\end{array}$ & O-LIP & $\begin{array}{l}\text { Collerson } \\
\text { et al. }{ }^{13}\end{array}$ & Ontong Java & & \\
\hline \multicolumn{12}{|c|}{ Diamond-bering ophiolites } \\
\hline Xigaze & 29.16 & 88.88 & 125 & $100-65$ & \multirow{7}{*}{$\begin{array}{l}\text { Yarlung } \\
\text { Zhangbo } \\
\text { belt, Tibet, } \\
\text { China }\end{array}$} & \multirow{7}{*}{$\begin{array}{l}\text { Xiong et al. } \\
(2016)\end{array}$} & \multirow{7}{*}{ O-LIP } & \multirow{7}{*}{$\begin{array}{l}\text { Yang and } \\
\text { Dilek }^{61} \text {, } \\
\text { Zhang et al. }^{60}\end{array}$} & \multirow{7}{*}{$\begin{array}{l}\text { Tibetan } \\
\text { oceanic } \\
\text { plateau }\end{array}$} & $(5)(7)$ & \multirow{7}{*}{$\begin{array}{l}\text { Dismem- } \\
\text { bered ophi- } \\
\text { olite, made } \\
\text { of several } \\
\text { bodies along } \\
\text { the Yarlung } \\
\text { Zhangbo bel }\end{array}$} \\
\hline Purang & 30.66 & 80.95 & 125 & $100-65$ & & & & & & $(5)(7)$ & \\
\hline Dangqiong & 30.23 & 83.19 & 125 & $100-65$ & & & & & & $(5)(7)$ & \\
\hline Lubuosa & 29.04 & 93.39 & 130 & $100-65$ & & & & & & $(5)(7)$ & \\
\hline Dongbo & 31.05 & 80.17 & 130 & $100-65$ & & & & & & $(5)(7)$ & \\
\hline Zedang & 29.18 & 91.61 & 160 & $100-65$ & & & & & & $(5)(7)$ & \\
\hline Dongqiao & 32.00 & 90.44 & 196 & $100-65$ & & & & & & $(5)(7)$ & \\
\hline Hegenshan & 44.75 & 116.39 & 295 & 244 & $\begin{array}{l}\text { Inner-Mon- } \\
\text { golia, China }\end{array}$ & $\begin{array}{l}\text { Huang et al. } \\
(2015)\end{array}$ & OIB & $\begin{array}{l}\text { Yang et al. } \\
(2015 a)\end{array}$ & Hegenshan & $(5)(7)$ & $\begin{array}{l}\text { Dismem- } \\
\text { bered } \\
\text { ophiolite }\end{array}$ \\
\hline Sartohay & 46.08 & 84.97 & 430 & 316 & $\begin{array}{l}\text { West Jungar, } \\
\text { China }\end{array}$ & $\begin{array}{l}\text { Tian et al. } \\
(2015)\end{array}$ & OIB & Miao et al. ${ }^{63}$ & West Jungar & $\begin{array}{l}(1)(3)(5) \\
(6)(7)\end{array}$ & \begin{tabular}{|l} 
Dismem- \\
bered \\
ophiolite
\end{tabular} \\
\hline Mirdita & 41.83 & 21.00 & 160 & 100 & Albania & $\begin{array}{l}\text { Xiong et al. } \\
(2017)\end{array}$ & OIB & $\begin{array}{l}\text { Gaggero } \\
\text { et al. }{ }^{65}\end{array}$ & Mirdita & $\begin{array}{l}(1)(3)(6) \\
(7)(8)\end{array}$ & $\begin{array}{l}\text { Semi-com- } \\
\text { plete section }\end{array}$ \\
\hline Myitkyina & 26.00 & 97.83 & 170 & $100-65$ & Myanmar & Chen et al. ${ }^{66}$ & n.a & & n.a & $(5 ?)(6 ?)(7)$ & \begin{tabular}{|l} 
Dismem- \\
bered \\
ophiolite
\end{tabular} \\
\hline Rai-Iz & 66.79 & 64.99 & 420 & 400 & Polar-Ural & $\begin{array}{l}\text { Yang et al. } \\
(2015)\end{array}$ & n.a & & n.a & $(3)(6 ?)(7)$ & $\begin{array}{l}\text { Dismem- } \\
\text { bered } \\
\text { ophiolite }\end{array}$ \\
\hline $\begin{array}{l}\text { Pozanti- } \\
\text { Karsanti }\end{array}$ & 37.70 & 35.36 & 95 & $100-65$ & Turkey & $\begin{array}{l}\text { Lian et al. } \\
(2017)\end{array}$ & n.a & & $\begin{array}{l}\text { Eastern Tau- } \\
\text { ride belt }\end{array}$ & $(4)(6)(7)(8)$ & $\begin{array}{l}\text { Semi-com- } \\
\text { plete section }\end{array}$ \\
\hline
\end{tabular}

Table 1. Oceanic diamond occurrences and relationship with oceanic large igneous provinces and ocean islands. m.y. million years, O-LIP oceanic large igneous provinces, OIB ocean island basalts, Lat. latitude, Long. longitude. (1), continental arc; (3), older oceanic arc; (4), oceanic arc; (5), oceanic plateau; (6), seamount and ocean island; (7), oceanic crusr; (8), mid-ocean ridge.

\section{Discussion}

Super-deep continental diamonds and oceanic diamonds share some characteristics. However, the extremely variable carbon isotopic composition of super-deep continental diamonds $\left(\delta^{13} \mathrm{C}\right.$ ranges from -28 to $3 \%$, average of $-8 \pm 9 \%$ o $)^{8,10,12}$ from one locality to another (Fig. $2 \mathrm{~b}$ ) is in stark contrast to the relatively homogenous carbon isotopic composition of oceanic diamonds $\left(\delta^{13} \mathrm{C}\right.$ range from -28 to $-19 \%$, average of $-25 \pm 4 \%$; Fig. $\left.2 \mathrm{c}\right)$, leading previous researchers to believe that they are of distinct carbon sources and therefore geneses and origins. A detailed examination reveals that some individual diamonds from the Juina- $5^{10}$ and Sao Luis (Brazil) ${ }^{8}$ continental super-deep diamonds exhibit carbon isotopic zonation, featuring very light $\mathrm{C}$ isotope fractions in their cores $\left(\delta^{13} \mathrm{C}\right.$ from -28 to $-20 \%$ ) and heavier, mantle-like $\mathrm{C}$ isotope compositions in the rims $\left(\delta^{13} \mathrm{C}-15 \% \text { to }-5 \% 0\right)^{8,10}$ (Fig. 2b). The Kankan diamonds represent a rare exception with dominantly $>-5 \% \mathrm{C}$ isotope (Fig. 2b). This general trend of very light isotope in the cores and heavy isotope in the rims is generally coupled with distinct cathodoluminescence colours between the cores and rims, interpreted as indicating pulses of diamond growth ${ }^{10}$.

Previously proposed models to explain the variability of carbon isotopic composition in super-deep continental diamonds include (1) primordial isotopic variability inherited from Earth's accretion ${ }^{76}$, (2) distinct carbon sources for the cores and rims (organic and inorganic) ${ }^{49-51}$, and (3) isotopic fractionation of carbon in the mantle $\mathrm{P}^{77,78}$.

The fact that (1) the highly negative carbon isotope values for the cores of the super-deep continental diamonds from Juina-5 and Sao Luis $\left(\delta^{13} \mathrm{C}-24 \pm 6 \%\right.$ ), and the overall homogeneous negative values for the superdeep diamonds from Jagersfontein $\left(\delta^{13} \mathrm{C} \text { up }-20 \pm 4 \%\right)^{11}$ and Monastery $\left(\delta^{13} \mathrm{C} \text { up }-17 \pm 1 \% \text { ) }\right)^{11}$, are comparable to those of the relatively homogeneous carbon isotopic composition of oceanic diamonds $\left(\delta^{13} \mathrm{C}-25 \pm 4 \%\right.$ ) (Fig. 2), and (2) they are believed to be of an organic origin from subducted slabs, can rule out the possibility of primordial origin and variability. The model involving fractionation processes during degassing of $\mathrm{CO}_{2}$ (enriched in ${ }^{13} \mathrm{C}$ ) and nitrogen is not supported either due to the lack of correlation between $\delta^{13} \mathrm{C}$ and nitrogen in various growth zones. ${ }^{8}$. This leads us to hypothesize that the very light cores of Juina- 5 and Sao Luis super-deep diamonds, and superdeep diamonds from Jagersfontein and Monastery, share a common origin with the oceanic diamonds, as reflected by their carbon isotope signatures (Fig. $2 \mathrm{~b}, \mathrm{c})$. Furthermore, the organic matter-like $\left(\delta^{13} \mathrm{C}\right.$ between -30 and $-20 \%{ }^{49,50}$ ) very light isotopic composition of such diamonds (Fig. 2b,c) from the mantle transition 

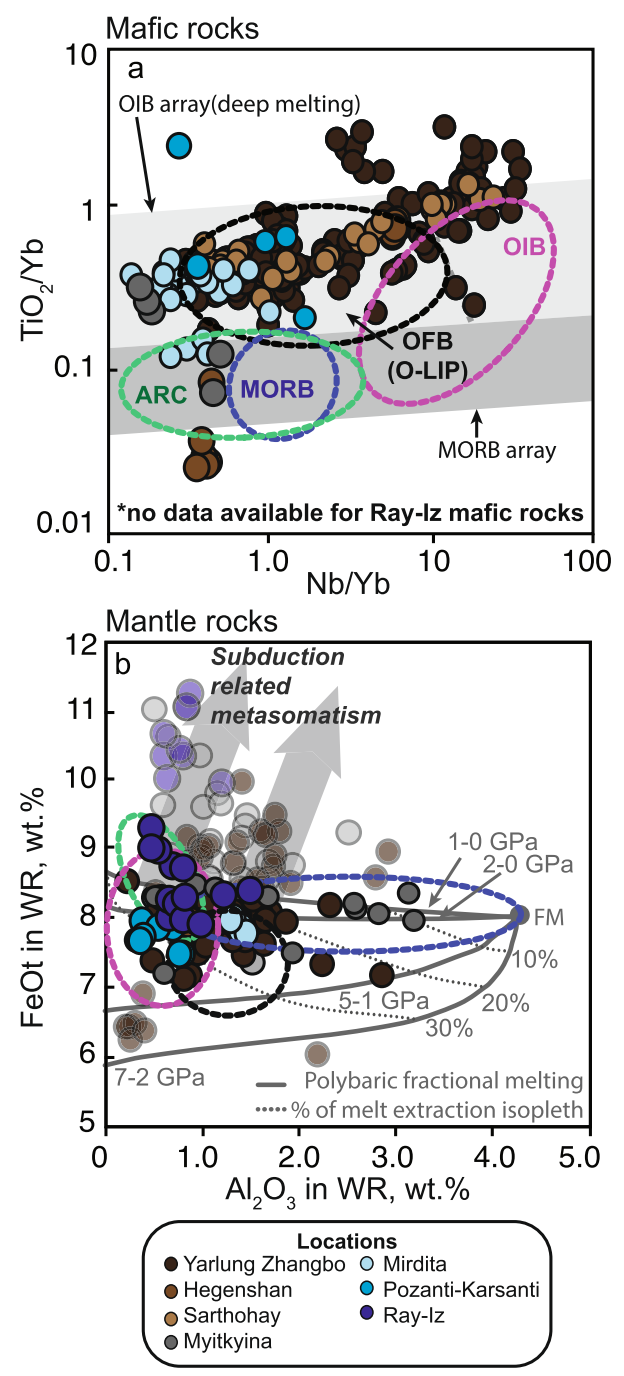

Figure 3. Geochemical characteristics of mafic and ultramafic rocks from diamond-bearing ophiolites plotted against fields of tectonic settings. (a) $\mathrm{Nb} / \mathrm{Yb}$ versus $\mathrm{TiO}_{2} / \mathrm{Yb}$ in mafic rocks, (b) $\mathrm{Al}_{2} \mathrm{O}_{3}$ versus FeOt (in wt. \%) in mantle rocks. See Supplementary Data Figure S2 for definition and sources of the tectonic setting discrimination fields. Also shown in (a) are the oceanic basalt (MORB) and ocean island basalt (OIB) discriminant fields (arrays) of Pearce ${ }^{67}$, and in (b) the experimental melting residue for polybaric fractional melting of fertile mantle ${ }^{68}$, with faded color shades showing data affected by subduction-related metasomatism ${ }^{69}$. Dotted ovals show fields of tectonic settings following the same color code as in (a).

zone argues for a common organic carbon origin. Most of the carbon (90\%) in the oceanic lithosphere is stored in the altered crust, while organic matter represents only a small fraction $(<10 \%)$ of the available carbon ${ }^{79,80}$. In view of the distinct organic carbon signature exhibited by the transition zone diamonds, it appears that organic carbon might be the dominant carbon available in the transition zone, and the transition zone likely plays a critical role in carbon cycles ${ }^{81}$.

Some mantle plumes are rooted from the lower mantle, whereas others could have a root near the transition zone, possibly as secondary plumes ${ }^{82,83}$, all above the large low-shear-velocity provinces (LLSVPs) in the lower mantle ${ }^{82,84,85}$. We envisage that mantle upwellings, caused by plumes ${ }^{86,87}$, entrain microdiamonds formed in the transition zone and transport them (and other associated ultra-high pressure minerals) to shallower levels ${ }^{88-93}$. In contrast, mantle convection around normal mid-ocean ridges, away from mantle plumes, do not contain such diamonds and ultra high-pressure minerals (Fig. 5). The high degree of melt extraction induced by mantle plumes is responsible for the formation of thicker $(100-140 \mathrm{~km})^{55,56}$ and highly depleted (in iron and other incompatible elements) oceanic lithospheric mantle ${ }^{59}$. Buoyancy caused by such depletion, along with plume-induced thermal buoyancy and the abnormal thickness of such plume-modified oceanic lithosphere ${ }^{94}$, makes it more resistant to subduction ${ }^{95}$, leading to components of it being accreted onto arcs and preserved in orogenic belts ${ }^{96}$. Subduction fluids modify the original chemical signature of the lithospheric mantle by melt-rock interactions at shallow depth during both accretion/obduction and exhumation in the spinel stability field $(<80 \mathrm{~km})$, leading to the formation of large podiform chromite bodies, typical of subduction zones ${ }^{16}$. During the accumulation processes of podiform chromite, oceanic diamonds are incorporated in newly formed high-Cr chromite ${ }^{97}$. Such 


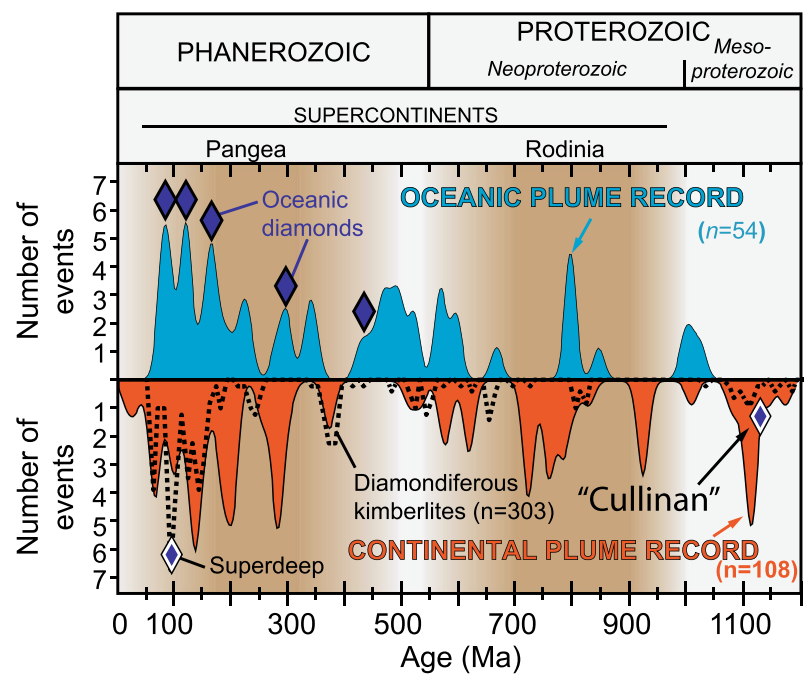

Figure 4. Distribution of diamond occurrences through time. The occurrences of oceanic diamonds (dark blue diamonds) ${ }^{13,14,16}$ and super deep diamonds (blue diamonds with white rims) s2,73 $^{7 r e}$ plotted against the time distributions of diamondiferous kimberlites (dotted curve) $)^{73}$, and oceanic (light blue) and continental (orange) mantle plume occurrences for the last 1200 million years ${ }^{33}$ and the life cycles of supercontinents Pangea and Rodinia ${ }^{74}$. Note that the majority of the known superdeep diamonds were brought up to the surface by 110-90 Ma kimberlites. The "Cullinan" (CLIPPIR) diamonds are from the much older Premier kimberlite $(1153 \mathrm{Ma})^{75}$.
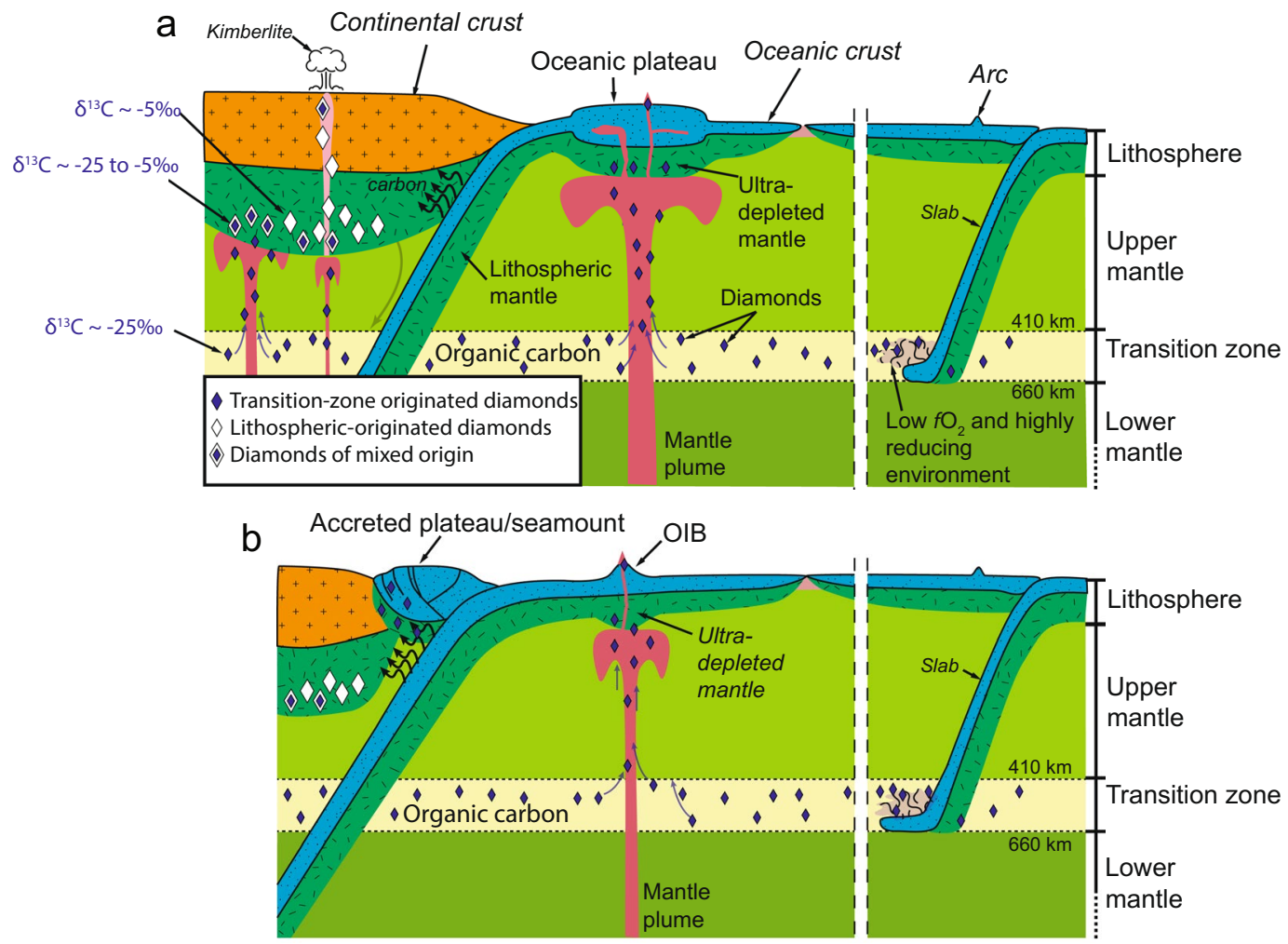

Figure 5. Model for the genesis of three types of diamonds. (A) Oceanic and super-deep continental diamonds (cores only) form in the mantle transition zone using subducted organic carbon, and are then brought to the lithospheric levels by mantle plumes. Continental diamonds grow or overgrow (as rims over the super-deep diamonds) in the continental lithosphere. (B) Oceanic diamond-bearing rocks are accreted onto continental margins as fragments of obducted oceanic plateaus or ocean islands.

a process is not only consistent with the deep and highly reduced origin of oceanic diamonds and associated 
ultra-high-pressure minerals and chromite, but also the subduction origin of the high-Cr podiform chromite.

Our model (Fig. 5) also provides a possible explanation for the extremely variable carbon isotopic composition of the super-deep continental diamonds (Fig. 2b) and the contrasting carbon isotope signatures of the three types of diamonds (Fig. 2). According to our model, mantle plumes bring the same super-deep microdiamonds, with homogeneous carbon isotopic composition, from the transition zone to the lithospheric levels of both the continental and oceanic realms (Fig. 5a) where they can potentially grow. Diamond growth is governed by conditions including the quantity of carbon available $\left(\mathrm{CO}, \mathrm{CO}_{2}, \mathrm{CH}_{4}\right)$, the pressure-temperature condition of the ambient environment $\left(\mathrm{P}>130-150 \mathrm{~km}\right.$ for $\left.\mathrm{T}>1000^{\circ} \mathrm{C}\right)$, the redox condition $\left(\Delta \log f \mathrm{O}_{2}\right.$ (oxygen fugacity) $\left.<-2\right)$ which controls the speciation of carbon and its precipitation ${ }^{98}$, and the time available for the growth to occur. The $\mathrm{P}-\mathrm{T}-\mathrm{fO}_{2}$ of the lithospheric mantle beneath the oldest continents (aka cratons) is known to favor the growth of diamond ${ }^{99}$. Such lithosphere is typically thicker (up to $300 \mathrm{~km}$ ), colder $\left(<900-1000{ }^{\circ} \mathrm{C}\right.$ ) and reduced (down to $\left.\Delta \log f \mathrm{O}_{2}<-4\right)^{100}$, contains sufficient amounts of carbon ${ }^{101}$, and is able to survive for a sufficiently long time. In such an environment, "purely" continental diamonds (white diamonds in Fig. 5) can grow to gemstone sizes with a homogeneous and predominantly lithospheric carbon isotope signature $\left(\delta^{13} \mathrm{C}-5 \%\right.$ o $)$ (Fig. 2a). Super-deep continental diamonds carried up by plumes (Fig. 5) can also grow rims there that share the same lithospheric carbon isotope signature $\left(\delta^{13} \mathrm{C}-10\right.$ to $0 \%$ ), yet their cores, of super-deep origin, retain their original lighter carbon isotopic signature which is the same as that of the oceanic diamonds $\left(\delta^{13} \mathrm{C}-25\right.$ to $-20 \%$ ) (Fig. 2).

The P-T- $\mathrm{fO}_{2}$ and duration of the oceanic plateau and ocean island lithosphere, on the other hand, are rather different although some parameters are still poorly constrained (e.g., a total lack of data on the redox state). The lithospheric mantle of oceanic plateaus and ocean islands is believed to be thinner $(<140 \mathrm{~km})^{55,58,102}$, hotter $\left(1000-1200^{\circ} \mathrm{C}\right)^{59}$, more oxidised $\left(\Delta \log f \mathrm{O}_{2}\right.$ from -3 to -1 according to limited data on mid-ocean ridge peridotites $)^{103}$, with less carbon available ${ }^{79}$, and recycled quickly through Wilson cycles. Oceanic microdiamonds, once incorporated in the thickened oceanic lithosphere by plumes, are thus suppressed from growth, or even totally frozen in size, shape (cubo-octahedral) and low aggregation state (Type Ib), due to such unfavorable conditions (Fig. 5) ${ }^{30}$. They therefore still retain their original narrow range and homogeneous carbon isotopic composition (Fig. 2c).

Our model thus provides a processes for the formation and emplacement of three major types of diamonds. Our model differs from that of Yang's group ${ }^{17}$ in that their model envisages widespread oceanic diamonds in the upper mantle, including in mid-ocean ridge environments, whereas in our model the occurrence of all three major types of diamonds are restricted to rocks linked to mantle plumes as our observations demonstrate (Fig. 1; Table 1). If correct, future work can use oceanic diamonds as a tracer for past oceanic mantle plume records in ophiolites formed through Earth's history, and to test competing geodynamic models ${ }^{33,70}$. Further testing of our model requires an improved mantle oxidation dataset from oceanic plateaus and ocean islands, and more stable isotope ratio and age data for oceanic diamonds.

\section{Methods}

Data compilation. We compiled the known occurrences of both present-day oceanic diamonds and those

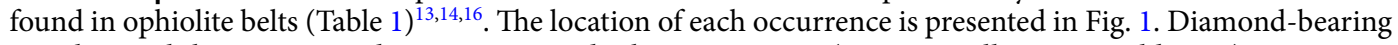
mantle xenoliths in present-day oceans provide the most recent (34-0.44 million years old, m.y.) occurrence of oceanic diamonds (Table 1). These modern oceanic diamonds are found in garnet-bearing xenoliths in the Salt Lake crater (0.44 m.y.) near Honolulu, Hawaii ${ }^{14}$, and from the alnoite pipe in the Malaita Islands (34 m.y., Solomon Islands) ${ }^{13}$ (Fig. 1). Diamond-bearing ophiolites contain much older oceanic diamonds (420-95 m.y.) (Table 1$)^{16}$ and include the Pozanti-Karsanti (also known as Aladag) ophiolite (ca. 95 m.y) in the eastern Tauride belt, Turkey; the Tibetan ophiolites (ca. 196-125 m.y.; the Luobusa, Dongqiao, Dangqiong, Xigaze, Dongbo, Zedang, and Purang ophiolites); the Mirdita ophiolite (c.a. 160 m.y.) in Albania; the Myitkynia ophiolite (ca. 170 m.y.) in Myanmar; the Hegenshan ophiolite (ca. 295 m.y.) in inner Mongolia, China; the Sartohay ophiolite (ca. 395 m.y.), part of the West Jungar belt, Xianjiang, China; and the Ray-Iz ophiolite (ca. 420 m.y.), in polar Ural, Russia.

Diamond-bearing ophiolites. A majority of diamond-bearing ophiolites are dismembered/mélange ophiolites ${ }^{60,104-108}$, with the exceptions of the Mirdita and Pozanti-Karsanti ophiolites which are often described as Penrose-type ophiolites ${ }^{107,109}$. We compiled the geological and geochemical information for the mafic and ultramafic rocks (when available) of these ophiolites (Fig. 3 and Table S1, Figures S3 and S4). The mafic rocks, representing the oceanic crust, and the ultramafic rocks, representing the oceanic lithospheric mantle, from all ophiolites share geochemical characteristics of deep melting products (Fig. 3). The mafic rocks are characterised by a garnet peridotitic source rock, illustrated by their high $\mathrm{TiO} 2 / \mathrm{Yb}, \mathrm{Nb} / \mathrm{Yb}$ and $\mathrm{Th} / \mathrm{Yb}$ (Fig. $3 \mathrm{a}$ and Figure S3), with major and trace element compositions similar to ocean island basalts and oceanic plateau basalts (Fig. 3a; Figures S2 and S3).

The ultramafic rocks consist of harzburgite and subordinate lherzolite and dunite. The lherzolites and dunites likely represent the products of post-melting metasomatism and melt-rock interaction, and are therefore not representative of the unaltered lithospheric mantle ${ }^{110}$. The harzburgites, representing the lithospheric mantle, are characterised by high $\mathrm{Mg} \#([\mathrm{Mg} /(\mathrm{Mg}+\mathrm{FeOt})$ at $]>0.91)$, low $\mathrm{Al}_{2} \mathrm{O}_{3}(1.5-0.2 \mathrm{wt} \%)$ and very minor $\mathrm{SiO}_{2}$ enrichments (Fig. 3b). Despite evidence for metasomatic enrichment in some harzburgites (e.g. enrichment of FeOt to $>9 \mathrm{wt} \%$, Fig. $3 \mathrm{~b}$ and S4), the least affected, and most refractory samples indicate an anhydrous melting origin by at least $30 \%$ of melt extraction at depths $>3 \mathrm{GPa}$ (Fig. $3 \mathrm{~b})^{68}$. Such a deep melting origin is supported by the absence of silica enrichment ${ }^{111}$ (Figure S4), an indicator for SSZ peridotites (Figure S2). In addition, garnetbreakdown features (i.e., spinel symplectite texture) have been reported in ophiolites from the Yarlung Zhangbo belt ${ }^{112}$, indicative of deep melting. 
Diamond classification. In this study we classify diamonds based on (1) nitrogen and boron contents as well as their configuration in the diamond lattice to define the "type" classification system ${ }^{113}$, and (2) their inclusions ${ }^{114,115}$ that defines their paragenesis ${ }^{3}$ and ultimately their lithospheric or sub-lithospheric provenances ${ }^{116,117}$.

Lithospheric diamonds are diamonds formed in the continental lithospheric mantle and have mineral inclusions of eclogite and peridotite typical of continental lithosphere mantle, including forsterite, pyrope, omphacite, diopside, enstatite, and sulfides. Lithospheric diamonds are commonly subdivided into "eclogitic" and "peridotitic", depending on the association of inclusions. For example, diamonds with almandine and omphacite inclusions are classified as eclogitic while diamonds with forsterite and pyrope are classified as peridotitic.

Superdeep (or sub-lithospheric) diamonds have mineral inclusions typical of the upper mantle, including ferro-periclase, $\mathrm{CaSiO}_{3}$-walstromite, jeffbenite, majoritic garnet and retrogressed bridgmanite. Superdeep diamond inclusions also indicate the depth of the diamonds, for example, diamonds with majoritic inclusions are believed to have come from the transition zone while diamonds with retro-morphosed bridgmanite are interpreted to have come from the lower mantle (a much rarer occurrence).

\section{Data availability}

Data needed to evaluate the conclusions in the paper are presented in the paper and/or the Supplementary Materials.

Received: 25 February 2021; Accepted: 5 August 2021

Published online: 20 August 2021

\section{References}

1. Richardson, S., Gurney, J., Erlank, A. \& Harris, J. Origin of diamonds in old enriched mantle. Nature 310, 198-202. https://doi. org/10.1038/310198a0 (1984).

2. Torsvik, T. H., Burke, K., Steinberger, B., Webb, S. J. \& Ashwal, L. D. Diamonds sampled by plumes from the core-mantle boundary. Nature 466, 352-355. https://doi.org/10.1038/nature09216 (2010).

3. Stachel, T. \& Harris, J. The origin of cratonic diamonds-constraints from mineral inclusions. Ore Geol. Rev. 34, 5-32. https:// doi.org/10.1016/j.oregeorev.2007.05.002 (2008).

4. Burke, K., Steinberger, B., Torsvik, T. H. \& Smethurst, M. A. Plume generation zones at the margins of large low shear velocity provinces on the core-mantle boundary. Earth Planet. Sci. Lett. 265, 49-60. https://doi.org/10.1016/j.epsl.2007.09.042 (2008).

5. Torsvik, T. H., Steinberger, B., Ashwal, L. D., Doubrovine, P. V. \& Trønnes, R. G. Earth evolution and dynamics-a tribute to Kevin Burke. Can. J. Earth Sci. 53, 1073-1087. https://doi.org/10.1139/cjes-2015-0228 (2016).

6. Nestola, F. et al. CaSiO3 perovskite in diamond indicates the recycling of oceanic crust into the lower mantle. Nature 555, 237. https://doi.org/10.1038/nature25972 (2018).

7. Kaminsky, F. V. et al. Superdeep diamonds from the Juina area, Mato Grosso State, Brazil. Contrib. Mineral. Petrol. 140, 734-753. https://doi.org/10.1016/j.lithos.2009.03.036 (2001).

8. Zedgenizov, D. A., Kagi, H., Shatsky, V. S. \& Ragozin, A. L. Local variations of carbon isotope composition in diamonds from São-Luis (Brazil): Evidence for heterogenous carbon reservoir in sublithospheric mantle. Chem. Geol. 363, 114-124. https:// doi.org/10.1016/j.chemgeo.2013.10.033 (2014).

9. Palot, M., Pearson, D., Stern, R., Stachel, T. \& Harris, J. Isotopic constraints on the nature and circulation of deep mantle C-HO-N fluids: Carbon and nitrogen systematics within ultra-deep diamonds from Kankan (Guinea). Geochim. Cosmochim. Acta 139, 26-46. https://doi.org/10.1016/j.gca.2014.04.027 (2014).

10. Thomson, A. et al. Origin of sub-lithospheric diamonds from the Juina-5 kimberlite (Brazil): Constraints from carbon isotopes and inclusion compositions. Contrib. Mineral. Petrol. 168, 1081. https://doi.org/10.1007/s00410-014-1081-8 (2014).

11. Palot, M. et al. The transition zone as a host for recycled volatiles: Evidence from nitrogen and carbon isotopes in ultra-deep diamonds from Monastery and Jagersfontein (South Africa). Chem. Geol. 466, 733-749. https://doi.org/10.1016/j.chemgeo. 2017.07.023 (2017).

12. Cartigny, P., Palot, M., Thomassot, E. \& Harris, J. W. Diamond formation: A stable isotope perspective. Annu. Rev. Earth Planet. Sci. 42, 699-732. https://doi.org/10.1146/annurev-earth-042711-105259 (2014).

13. Collerson, K. D., Hapugoda, S., Kamber, B. S. \& Williams, Q. Rocks from the mantle transition zone: Majorite-bearing xenoliths from Malaita, Southwest Pacific. Science 288, 1215-1223. https://doi.org/10.1126/science.288.5469.1215 (2000).

14. Wirth, R. \& Rocholl, A. Nanocrystalline diamond from the Earth's mantle underneath Hawaii. Earth Planet. Sci. Lett. 211, 357-369. https://doi.org/10.1016/S0012-821X(03)00204-8 (2003).

15. Yang, J., Robinson, P. T. \& Dilek, Y. Diamond-bearing ophiolites and their geological occurrence. Episodes 38, 344-364 (2015).

16. Lian, D. \& Yang, J. Ophiolite-hosted diamond: A new window for probing carbon cycling in the deep mantle. Engineering https:// doi.org/10.1016/j.eng.2019.02.006 (2019).

17. Yang, J., Wu, W., Lian, D. \& Rui, H. Peridotites, chromitites and diamonds in ophiolites. Nat. Rev. Earth Environ. https://doi. org/10.1038/s43017-020-00138-4 (2021).

18. Litasov, K. D., Kagi, H., Bekker, T. B., Hirata, T. \& Makino, Y. Cuboctahedral type Ib diamonds in ophiolitic chromitites and peridotites: The evidence for anthropogenic contamination. High Press. Res. 39, 480-488. https://doi.org/10.1080/08957959. 2019.1616183 (2019).

19. Litasov, K. et al. Comparison of enigmatic diamonds from the Tolbachik arc volcano (Kamchatka) and Tibetan ophiolites: Assessing the role of contamination by synthetic materials. Gondwana Res. 75, 16-27. https://doi.org/10.1016/j.gr.2019.04.007 (2019).

20. Howell, D. et al. Diamonds in ophiolites: Contamination or a new diamond growth environment?. Earth Planet. Sci. Lett. 430, 284-295. https://doi.org/10.1016/j.epsl.2015.08.023 (2015).

21. Yang, J. et al. Comment on "Comparison of enigmatic diamonds from the Tolbachik arc volcano (Kamchatka) and Tibetan ophiolites: Assessing the role of contamination by synthetic materials" by Litasov et al. 2019. Gondwana Res. 79, 301-303. https:// doi.org/10.1016/j.gr.2019.09.010 (2020).

22. Griffin, W. L., Toledo, V. \& O'Reilly, S. Y. Discussion of" Enigmatic super-reduced phases in corundum from natural rocks: Possible contamination from artificial abrasive materials or metallurgical slags" by Litasov et al.(Lithos, 340-341, p. 181-190). Lithos 348, 105122. https://doi.org/10.1016/j.lithos.2019.06.024 (2019).

23. Yang, J.-S. et al. Diamond- and coesite-bearing chromitites from the Luobusa ophiolite, Tibet. Geology 35, 875-878. https://doi. org/10.1130/G23766A.1 (2007). 
24. Das, S., Basu, A. \& Mukherjee, B. In situ peridotitic diamond in Indus ophiolite sourced from hydrocarbon fluids in the mantle transition zone. Geology 45, 755-758. https://doi.org/10.1130/G39100.1 (2017).

25. Pujol Solà, N., García Casco, A., González Jiménez, J. \& Sánchez Navas, A. Diamond forms during low pressure serpentinisation of oceanic lithosphere. Geochem. Perspect. Lett. https://doi.org/10.7185/geochemlet.2029 (2020).

26. Dobrzhinetskaya, L. F. et al. High-pressure highly reduced nitrides and oxides from chromitite of a Tibetan ophiolite. Proc. Natl. Acad. Sci. 106, 19233-19238. https://doi.org/10.1073/pnas.0905514106 (2009).

27. Yang, J. et al. Diamonds, native elements and metal alloys from chromitites of the Ray-Iz ophiolite of the Polar Urals. Gondwana Res. 27, 459-485. https://doi.org/10.1016/j.gr.2014.07.004 (2015).

28. Simakov, S., Dubinchuk, V., Novikov, M. \& Drozdova, I. In Doklady Earth Sciences. 835 (Springer Nature BV).

29. Simakov, S. Metastable nanosized diamond formation from a C-H-O fluid system. J. Mater. Res. 25, 2336-2340. https://doi. org/10.1557/jmr.2010.0303 (2010).

30. Xu, X. et al. Fourier transform infrared spectroscopy data and carbon isotope characteristics of the ophiolite-hosted diamonds from the Luobusa ophiolite, Tibet, and Ray-Iz ophiolite, Polar Urals. Lithosphere 10, 156-169. https://doi.org/10.1130/L625.1 (2018).

31. Dobrzhinetskaya, L. F. Microdiamonds-frontier of ultrahigh-pressure metamorphism: A review. Gondwana Res. 21, 207-223. https://doi.org/10.1016/j.gr.2011.07.014 (2012).

32. Wu, W. et al. Carbon and nitrogen isotopes and mineral inclusions in diamonds from chromitites of the Mirdita ophiolite (Albania) demonstrate recycling of oceanic crust into the mantle. Am. Mineral. J. Earth Planet. Materials 104, 485-500. https:// doi.org/10.2138/am-2019-6751 (2019).

33. Doucet, L. S. et al. Coupled supercontinent-mantle plume events evidenced by oceanic plume record. Geology 48(2), 159-163. https://doi.org/10.1130/G46754.1 (2020).

34. Matthews, K. J. et al. Global plate boundary evolution and kinematics since the late Paleozoic. Glob. Planet. Change 146, 226-250 (2016).

35. Haggerty, S. E. Micro-diamonds: Proposed origins, crystal growth laws, and the underlying principle governing resource predictions. Geochim. Cosmochim. Acta 266, 184-196. https://doi.org/10.1016/j.gca.2019.03.036 (2019).

36. Smith, E. M. et al. Large gem diamonds from metallic liquid in Earth's deep mantle. Science 354, 1403-1405. https://doi.org/10. 1126/science.aal1303 (2016).

37. Walter, M. J. et al. Primary carbonatite melt from deeply subducted oceanic crust. Nature 454, 622-625. https://doi.org/10.1038/ nature07132 (2008).

38. Bulanova, G. P. et al. Mineral inclusions in sublithospheric diamonds from Collier 4 kimberlite pipe, Juina, Brazil: Subducted protoliths, carbonated melts and primary kimberlite magmatism. Contrib. Mineral Petrol 160, 489-510. https://doi.org/10.1007/ s00410-010-0490-6 (2010).

39. Smart, K. A. et al. Diamond growth from oxidized carbon sources beneath the Northern Slave Craton, Canada: A $\delta 13 \mathrm{C}-\mathrm{N}$ study of eclogite-hosted diamonds from the Jericho kimberlite. Geochim. Cosmochim. Acta 75, 6027-6047 (2011).

40. Thomson, A. R., Walter, M. J., Kohn, S. C. \& Brooker, R. A. Slab melting as a barrier to deep carbon subduction. Nature 529, 76-79. https://doi.org/10.1038/nature16174 (2016)

41. Thomson, A. et al. Trace element composition of silicate inclusions in sub-lithospheric diamonds from the Juina-5 kimberlite: Evidence for diamond growth from slab melts. Lithos 265, 108-124. https://doi.org/10.1016/j.lithos.2016.08.035 (2016).

42. Yang, J.-S., Robinson, P. T. \& Dilek, Y. Diamonds in ophiolites. Elements 10, 127-130. https://doi.org/10.2113/gselements.10.2. 127 (2014).

43. Pearson, D. et al. Hydrous mantle transition zone indicated by ringwoodite included within diamond. Nature 507, 221. https:// doi.org/10.1038/nature13080 (2014).

44. Lian, D. et al. Carbon and nitrogen isotope, and mineral inclusion studies on the diamonds from the Pozanti-Karsanti chromitite, Turkey. Contrib. Mineral Petrol. 173, 1-18. https://doi.org/10.1007/s00410-018-1499-5 (2018).

45. Brenker, F. E. et al. Carbonates from the lower part of transition zone or even the lower mantle. Earth Planet. Sci. Lett. 260, 1. https://doi.org/10.1016/j.epsl.2007.02.038 (2007).

46. Kaminsky, F., Wirth, R., Matsyuk, S., Schreiber, A. \& Thomas, R. Nyerereite and nahcolite inclusions in diamond: Evidence for lower-mantle carbonatitic magmas. Mineral. Mag. 73, 797-816. https://doi.org/10.1180/minmag.2009.073.5.797 (2009).

47. Kaminsky, F. V., Wirth, R. \& Schreiber, A. Carbonatitic inclusions in deep mantle diamond from Juina, Brazil: New minerals in the carbonate-halide association. Can. Mineral. 51, 669-688. https://doi.org/10.3749/canmin.51.5.669 (2013).

48. Deines, P. The carbon isotope geochemistry of mantle xenoliths. Earth-Sci. Rev. 58, 247-278. https://doi.org/10.1016/S00128252(02)00064-8 (2002)

49. Veizer, J. \& Hoefs, J. The nature of O18/O16 and C13/C12 secular trends in sedimentary carbonate rocks. Geochim. Cosmochim. Acta 40, 1387-1395. https://doi.org/10.1016/0016-7037(76)90129-0 (1976).

50. Schidlowski, M. Carbon isotopes as biogeochemical recorders of life over $38 \mathrm{Ga}$ of Earth history: Evolution of a concept. Precambrian Res. 106, 117-134. https://doi.org/10.1016/S0301-9268(00)00128-5 (2001).

51. Eigenbrode, J. L. \& Freeman, K. H. Late Archean rise of aerobic microbial ecosystems. Proc. Natl. Acad. Sci. 103, 15759-15764. https://doi.org/10.1073/pnas.0607540103 (2006).

52. Arai, S. Conversion of low-pressure chromitites to ultrahigh-pressure chromitites by deep recycling: A good inference. Earth Planet. Sci. Lett. 379, 81-87. https://doi.org/10.1016/j.epsl.2013.08.006 (2013).

53. Griffin, W. L. et al. Mantle recycling: transition zone metamorphism of Tibetan ophiolitic peridotites and its tectonic implications. J. Petrol. 57, 655-684. https://doi.org/10.1093/petrology/egw011 (2016).

54. Dilek, Y. \& Furnes, H. Ophiolite genesis and global tectonics: Geochemical and tectonic fingerprinting of ancient oceanic lithosphere. Geol. Soc. Amer. Bull. 123, 387-411 (2011).

55. Ishikawa, A., Maruyama, S. \& Komiya, T. Layered lithospheric mantle beneath the Ontong Java Plateau: Implications from xenoliths in alnoite, malaita, Solomon Islands. J. Petrol. 45, 2011-2044. https://doi.org/10.1093/petrology/egh046 (2004).

56. Tharimena, S., Rychert, C. A. \& Harmon, N. Seismic imaging of a mid-lithospheric discontinuity beneath Ontong Java Plateau. Earth Planet. Sci. Lett. 450, 62-70. https://doi.org/10.1016/j.epsl.2016.06.026 (2016).

57. Neal, C. R., Haggerty, S. E. \& Sautter, V. "Majorite" and "silicate perovskite" mineral compositions in xenoliths from Malaita. Science 292, 1015-1015. https://doi.org/10.1126/science.292.5519.1015a (2001).

58. Isse, T. et al. Seismic evidence for a thermochemical mantle plume underplating the lithosphere of the Ontong Java Plateau. Commun. Earth Environ. 2, 1-7. https://doi.org/10.1038/s43247-021-00169-9 (2021).

59. Simon, N. S. C. et al. Ultra-refractory domains in the oceanic mantle lithosphere sampled as mantle xenoliths at ocean islands. J. Petrol. 49, 1223-1251. https://doi.org/10.1093/petrology/egn023 (2008).

60. Zhang, K.-J. et al. Central Tibetan Meso-Tethyan oceanic plateau. Lithos 210-211, 278-288. https://doi.org/10.1016/j.lithos. 2014.09.004 (2014).

61. Yang, G. \& Dilek, Y. OIB-and P-type ophiolites along the Yarlung-Zangbo Suture Zone (YZSZ), Southern Tibet: Poly-phase melt history and mantle sources of the Neotethyan oceanic lithosphere. Episodes 38, 250-265. https://doi.org/10.18814/epiiu gs/2015/v38i4/82420 (2015).

62. Yang, G., Li, Y., Xiao, W. \& Tong, L. OIB-type rocks within West Junggar ophiolitic mélanges: Evidence for the accretion of seamounts. Earth Sci. Rev. 150, 477-496. https://doi.org/10.1016/j.earscirev.2015.09.002 (2015). 
63. Miao, L. et al. Geochronology and geochemistry of the Hegenshan ophiolitic complex: Implications for late-stage tectonic evolution of the Inner Mongolia-Daxinganling Orogenic Belt, China. J. Asian Earth Sci. 32, 348-370. https://doi.org/10.1016/j. jseaes.2007.11.005 (2008).

64. Göncüoğlu, M. C. In Mineral Resources of Turkey Vol. 1 (eds F. Pirajno, T. Ünlü, C.M. Dönmez, \& M. Bahamir Şahin) 19-72 (Springer, 2019).

65. Gaggero, L., Marroni, M., Pandolfi, L. \& Buzzi, L. Modelling of oceanic lithosphere obduction: Constraints from the metamorphic sole of Mirdita ophiolites (Northern Albania). Ofioliti 34, 17-42. https://doi.org/10.4454/ofioliti.v34i1.376 (2009).

66. Chen, Y., Yang, J., Xu, Z., Tian, Y. \& Lai, S. Diamonds and other unusual minerals from peridotites of the Myitkyina ophiolite, Myanmar. J. Asian Earth Sci. 164, 179-193. https://doi.org/10.1016/j.jseaes.2018.06.018 (2018).

67. Pearce, J. A. Geochemical fingerprinting of oceanic basalts with applications to ophiolite classification and the search for Archean oceanic crust. Lithos 100, 14-48. https://doi.org/10.1016/j.lithos.2007.06.016 (2008).

68. Herzberg, C. Geodynamic information in peridotite petrology. J. Petrol 45, 2507-2530. https://doi.org/10.1093/petrology/egh039 (2004).

69. Malvoisin, B. Mass transfer in the oceanic lithosphere: Serpentinization is not isochemical. Earth Planet. Sci. Lett. 430, 75-85 (2015).

70. Li, Z.-X. \& Zhong, S. Supercontinent-superplume coupling, true polar wander and plume mobility: Plate dominance in wholemantle tectonics. Phys. Earth Planet. Inter. 176, 143-156. https://doi.org/10.1016/j.pepi.2009.05.004 (2009).

71. Gamal-El-Dien, H., Doucet, L. S., Li, Z.-X., Cox, M. C. \& Mitchell, R. N. Global geochemical fingerprinting of plume intensity suggests coupling with the supercontinent cycle. Nat. Commun. 10, 1-7. https://doi.org/10.1038/s41467-019-13300-4 (2019).

72. Gurney, J. J., Helmstaedt, H. H., Richardson, S. H. \& Shirey, S. B. Diamonds through time. Econ. Geol. 105, 689-712. https:// doi.org/10.2113/gsecongeo.105.3.689 (2010).

73. Tappe, S., Smart, K., Torsvik, T., Massuyeau, M. \& de Wit, M. Geodynamics of kimberlites on a cooling Earth: Clues to plate tectonic evolution and deep volatile cycles. Earth Planet. Sci. Lett. 484, 1-14. https://doi.org/10.1016/j.epsl.2017.12.013 (2018).

74. Li, Z. X. et al. Decoding Earth's rhythms: Modulation of supercontinent cycles by longer superocean episodes. Precambr. Res. 323, 1-5. https://doi.org/10.1016/j.precamres.2019.01.009 (2019)

75. Tappe, S., Dongre, A., Liu, C.-Z. \& Wu, F.-Y. 'Premier'evidence for prolonged kimberlite pipe formation and its influence on diamond transport from deep Earth. Geology 46, 843-846. https://doi.org/10.1130/G45097.1 (2018).

76. Palot, M., Cartigny, P., Harris, J., Kaminsky, F. \& Stachel, T. Evidence for deep mantle convection and primordial heterogeneity from nitrogen and carbon stable isotopes in diamond. Earth Planet. Sci. Lett. 357, 179-193. https://doi.org/10.1016/j.epsl.2012. 09.015 (2012)

77. Cartigny, P., Harris, J. W., Phillips, D., Girard, M. \& Javoy, M. Subduction-related diamonds? The evidence for a mantle-derived origin from coupled $\mathrm{d}^{13} \mathrm{C}-\mathrm{d}^{15} \mathrm{~N}$ determinations. Chem. Geol. 147, 147-159. https://doi.org/10.1016/S0009-2541(97)00178-2 (1998).

78. Cartigny, P., Harris, J. W. \& Javoy, M. Diamond genesis, mantle fractionations and mantle nitrogen content: A study of delta13C$\mathrm{N}$ concentrations in diamonds. Earth. Planet. Sci. Lett. 185, 85-98. https://doi.org/10.1016/S0012-821X(00)00357-5 (2001).

79. Kelemen, P. B. \& Manning, C. E. Reevaluating carbon fluxes in subduction zones, what goes down, mostly comes up. Proc. Natl. Acad. Sci. 112, E3997-E4006. https://doi.org/10.1073/pnas.1507889112 (2015).

80. Li, K., Li, L., Pearson, D. G. \& Stachel, T. Diamond isotope compositions indicate altered igneous oceanic crust dominates deep carbon recycling. Earth Planet. Sci. Lett. 516, 190-201. https://doi.org/10.1016/j.epsl.2019.03.041 (2019).

81. Regier, M. et al. The lithospheric-to-lower-mantle carbon cycle recorded in superdeep diamonds. Nature 585, 234-238. https:// doi.org/10.1038/s41586-020-2676-z (2020).

82. Courtillot, V., Davaille, A., Besse, J. \& Stock, J. Three distinct types of hotspots in the Earth's mantle. Earth Planet. Sci. Lett. 205, 295-308. https://doi.org/10.1016/S0012-821X(02)01048-8 (2003).

83. Wang, X.-C. et al. Identification of an ancient mantle reservoir and young recycled materials in the source region of a young mantle plume: Implications for potential linkages between plume and plate tectonics. Earth Planet. Sci. Lett. 377-378, 248-259. https://doi.org/10.1016/j.epsl.2013.07.003 (2013).

84. Koppers, A. A. Mantle plumes persevere. Nat. Geosci. 4, 816-817. https://doi.org/10.1038/ngeo1334 (2011).

85. Garnero, E. J., McNamara, A. K. \& Shim, S.-H. Continent-sized anomalous zones with low seismic velocity at the base of Earth's mantle. Nat. Geosci. 9, 481. https://doi.org/10.1038/ngeo2733 (2016).

86. Maclennan, J., McKenzie, D. \& Gronvöld, K. Plume-driven upwelling under central Iceland. Earth Planet. Sci. Lett. 194, 67-82. https://doi.org/10.1016/S0012-821X(01)00553-2 (2001).

87. Sobolev, A. V., Hofmann, A. W., Jochum, K. P., Kuzmin, D. V. \& Stoll, B. A young source for the Hawaiian plume. Nature 476, 434-437. https://doi.org/10.1038/nature10321 (2011).

88. Griffin, W. L. et al. Layered mantle lithosphere in the Lac de Gras Area, Slave Craton: Composition, structure and origin. J. Petrol. 40, 705-727. https://doi.org/10.1093/petroj/40.5.705 (1999).

89. Davies, R. M., Griffin, W. L., O’Reilly, S. Y. \& Doyle, B. J. Mineral inclusions and geochemical characteristics of microdiamonds from the DO27, A154, A21, A418, DO18, DD17 and Ranch Lake kimberlites at Lac de Gras, Slave Craton, Canada. Lithos 77, 39-55. https://doi.org/10.1016/j.lithos.2004.04.016 (2004).

90. Harte, B. \& Cayzer, N. Decompression and unmixing of crystals included in diamonds from the mantle transition zone. Phys. Chem. Miner. 34, 647-656. https://doi.org/10.1007/s00269-007-0178-2 (2007).

91. Walter, M. et al. Deep mantle cycling of oceanic crust: Evidence from diamonds and their mineral inclusions. Science 334, 54-57. https://doi.org/10.1126/science.1209300 (2011).

92. Tappe, S., Pearson, D. G., Kjarsgaard, B. A., Nowell, G. \& Dowall, D. Mantle transition zone input to kimberlite magmatism near a subduction zone: Origin of anomalous Nd-Hf isotope systematics at Lac de Gras, Canada. Earth Planet. Sci. Lett. 371, 235-251. https://doi.org/10.1016/j.epsl.2013.03.039 (2013)

93. Tappe, S., Budde, G., Stracke, A., Wilson, A. \& Kleine, T. The tungsten-182 record of kimberlites above the African superplume: Exploring links to the core-mantle boundary. Earth Planet. Sci. Lett. 547, 116473. https://doi.org/10.1016/j.epsl.2020.116473 (2020).

94. Kerr, A. C. In Treatise on Geochemistry (eds H. D. Holland \& K. K. Turekian) 537-565 (Pergamon, 2003).

95. Cloos, M. Lithospheric buoyancy and collisional orogenesis: Subduction of oceanic plateaus, continental margins, island arcs, spreading ridges, and seamounts. Geol. Soc. Am. Bull. 105, 715-737. https://doi.org/10.1130/0016-7606(1993)105\%3c0715: LBACOS\%3e2.3.CO;2 (1993).

96. Coffin, M. F. \& Eldholm, O. Large igneous provinces: Progenitors of some ophiolites?. Mantle Plumes Identif. Time 352, 59. https://doi.org/10.1130/0-8137-2352-3.59 (2001).

97. Shi, R. et al. Multiple events in the Neo-Tethyan oceanic upper mantle: Evidence from Ru-Os-Ir alloys in the Luobusa and Dongqiao ophiolitic podiform chromitites, Tibet. Earth Planet. Sci. Lett. 261, 33. https://doi.org/10.1016/j.epsl.2007.05.044 (2007).

98. Jablon, B. M. \& Navon, O. Most diamonds were created equal. Earth Planet. Sci. Lett. 443, 41-47. https://doi.org/10.1016/j.epsl. 2016.03.013 (2016).

99. Howell, D. et al. Deep carbon through time: Earth's diamond record and its implications for carbon cycling and fluid speciation in the mantle. Geochim. Cosmochim. Acta 275, 99-122. https://doi.org/10.1016/j.gca.2020.02.011 (2020) 
100. Goncharov, A. G., Ionov, D. A., Doucet, L. S. \& Pokhilenko, L. N. Thermal state, oxygen fugacity and C-O-H fluid speciation in cratonic lithospheric mantle: New data on peridotite xenoliths from the Udachnaya kimberlite, Siberia. Earth Planet. Sci. Lett. 357-358, 99-110. https://doi.org/10.1016/j.epsl.2012.09.016 (2012).

101. Dasgupta, R. \& Hirschmann, M. M. The deep carbon cycle and melting in Earth's interior. Earth Planet. Sci. Lett. 298, 1-13. https://doi.org/10.1016/j.epsl.2010.06.039 (2010).

102. Priestley, K. \& Tilmann, F. Shear-wave structure of the lithosphere above the Hawaiian hot spot from two-station Rayleigh wave phase velocity measurements. Geophys. Res. Lett. 26, 1493-1496. https://doi.org/10.1029/1999GL900299 (1999).

103. Bryndzia, T. L., Wood, B. J. \& Dick, H. J. B. The oxidation state of the earth's sub-oceanic mantle from oxygen thermobarometry of abyssal spinel peridotites. Nature 341, 526-527. https://doi.org/10.1038/341526a0 (1989).

104. Kazak, A., Dobretsov, N. \& Moldavantsev, Y. E. Glaucophane schists, jadeitites, vesuvianites and nephrites of the ultrabasitic Rai-Iz massif. Geol. Geophys. 2, 60-66 (1976).

105. Mitchell, A. Cretaceous-Cenozoic tectonic events in the western Myanmar (Burma)-Assam region. J. Geol. Soc. 150, $1089-1102$. https://doi.org/10.1144/gsigs.150.6.1089 (1993).

106. Peng, G. Podiform Chromite and Associated Ophiolitic Rocks in West Junggar, Xinjiang, China. Ph.D. thesis (1995).

107. Parlak, O., Höck, V. \& Delaloye, M. Suprasubduction zone origin of the Pozanti-Karsanti ophiolite (southern Turkey) deduced from whole-rock and mineral chemistry of the gabbroic cumulates. Geol. Soc. Lond. Spec. Publ. 173, 219-234. https://doi.org/ 10.1144/GSL.SP.2000.173.01.11 (2000).

108. Nozaka, T. \& Liu, Y. Petrology of the Hegenshan ophiolite and its implication for the tectonic evolution of northern China. Earth Planet. Sci. Lett. 202, 89-104. https://doi.org/10.1016/S0012-821X(02)00774-4 (2002).

109. Dilek, Y., Shallo, M. \& Furnes, H. Rift-drift, seafloor spreading, and subduction tectonics of Albanian ophiolites. Int. Geol. Rev. 47, 147-176. https://doi.org/10.2747/0020-6814.47.2.147 (2005).

110. Kelemen, P. B., Shimizu, N. \& Salters, V. Extraction of mid-ocean-ridge basalt from the upwelling mantle by focused flow of melt in dunite channels. Nature 375, 747-753. https://doi.org/10.1038/375747a0 (1995).

111. Bénard, A., Arculus, R. J., Nebel, O., Ionov, D. A. \& McAlpine, S. R. B. Silica-enriched mantle sources of subalkaline picriteboninite-andesite island arc magmas. Geochim. Cosmochim. Acta 199, 287-303. https://doi.org/10.1016/j.gca.2016.09.030 (2017).

112. Gong, X. H. et al. "Garnet" Lherzolites in the Purang Ophiolite, Tibet: Evidence for exhumation of deep oceanic lithospheric mantle. Geophys. Res. Lett. 47, e2019GL086101. https://doi.org/10.1029/2019GL086101 (2020).

113. Breeding, C. M. \& Shigley, J. E. The, "type" classification system of diamonds and its importance in gemology. Gems Gemol. 45, 96-111 (2009).

114. Harris, J. Recognition of diamond inclusions. 1. Syngenetic mineral inclusions. Ind. Diam. Rev. 28, 402-410 (1968).

115. Harris, J. Recognition of diamond inclusions. 2. Epigenetic mineral inclusions. Indu. Diam. Rev. 28, 558-561 (1968).

116. Nestola, F. Inclusions in super-deep diamonds: windows on the very deep Earth. Rend. Lincei 28, 595-604. https://doi.org/10. 1007/s12210-017-0607-1 (2017).

117. Shirey, S. B. et al. Diamonds and the geology of mantle carbon. Rev. Mineral. Geochem. 75, 355-421. https://doi.org/10.2138/ rmg.2013.75.12 (2013).

\section{Acknowledgements}

We thank Josh Beardmore for his support and proofreading, and other members of the Earth Dynamics Research group for useful discussions. This is a contribution to IGCP 648. This work was supported by the Australian Research Council Laureate Fellowship grant to ZXL (FL150100133). We thank S. Tappe and anonymous reviewers for their constructive comments on earlier versions of the manuscript.

\section{Author contributions}

L.S.D. led the research, compiled the data, and drafted the manuscript. Z.X.L. established the framework with L.S.D., clarified the concepts and models, and wrote the manuscript. H.G. provided expertise on ophiolitic rocks and chromitite petrogenesis.

\section{Competing interests}

The authors declare no competing interests.

\section{Additional information}

Supplementary Information The online version contains supplementary material available at https://doi.org/ 10.1038/s41598-021-96286-8.

Correspondence and requests for materials should be addressed to L.S.D. or Z.-X.L.

Reprints and permissions information is available at www.nature.com/reprints.

Publisher's note Springer Nature remains neutral with regard to jurisdictional claims in published maps and institutional affiliations.

Open Access This article is licensed under a Creative Commons Attribution 4.0 International License, which permits use, sharing, adaptation, distribution and reproduction in any medium or format, as long as you give appropriate credit to the original author(s) and the source, provide a link to the Creative Commons licence, and indicate if changes were made. The images or other third party material in this article are included in the article's Creative Commons licence, unless indicated otherwise in a credit line to the material. If material is not included in the article's Creative Commons licence and your intended use is not permitted by statutory regulation or exceeds the permitted use, you will need to obtain permission directly from the copyright holder. To view a copy of this licence, visit http://creativecommons.org/licenses/by/4.0/.

(C) The Author(s) 2021 